\title{
Assessing Factors Affecting FDI in Developing Asian Countries
}

\author{
Parul Gupta
}

\begin{abstract}
The paper focuses on various factors that affect the inflow of Foreign Direct Investment in developing countries. The study majorly deals with Asian countries, namely India, China, Myanmar, Nepal, Pakistan, Bangladesh and Bhutan, that are progressing from being aid-dependent to trading giants. The factors affecting FDI are majorly categorised into dependent and independent variables. Here, in this study, the dependent variable considered is FDI inflow, and independent variables are market size, the value of the currency, export, import, gross fixed capital formation, GDP deflator, cost of borrowing and economic reforms. Pooled Ordinary Least Square (OLS), fixed effect and random effect regression analysis is done to ascertain the best regression model and various tests are performed to check the intensity of effect caused by each independent variable on our dependent variable.

Keywords: Foreign Direct Investment (FDI); Gross Domestic Product (GDP); Ordinary Least Square (OLS); Gross Fixed Capital Formation (GFCF)

JEL Classification: G11, G15, G31

(C) Parul Gupta, 2021
\end{abstract}

\section{Introduction}

World Bank has succinctly defined FDI as "the net inflows (or outflows) of investment to acquire a lasting management interest in an enterprise operating in an economy other than that of the investor. It is the sum of equity capital, reinvestment of earnings and other long terms as well as short term capital as mentioned in the balance of payments."

FDI gained attention in the international economy after World War II. Numerous studies have been laid so far for an enhanced understanding of economic mechanisms and behaviour of economic agents at both micro and macro levels. FDIs are promoted by relatively open economies that are ready to welcome not just capital investment but technology and management also as FDI"s are categorised by ownership control of the business enterprise.

According to The Financial Times, "Control of management, technology and other crucial inputs can confer de facto control".

United Nations Conference on Trade and Development (UNCTAD) said, "South Asia recorded a $10 \%$ increase in FDI to $\$ 60$ billion. The growth was driven by India, with a 16 per cent increase in inflows to an estimated $\$ 40$ billion registering itself among the top ten recipients of overseas investment. The majority went into services industries, including information technology." "Among developing economies, the Asia- Pacific region received the largest share of global FDI inflows attracting 45 per cent in 2018. Developing countries in the region attracted 40 per cent of global FDI inflows, converted into 88 per cent of total Asia- Pacific region inflows. Over the past decade, the share of intra-region greenfield inflows increased from 40 to 45 per cent. East and North-East Asia accounted for 66 per cent of all intra- regional greenfield FDI outflows."

The factors affecting FDI differs with both longitudinal and latitudinal changes. As conditions across countries vary, how they attract FDI also changes depending on the initial economic development, regulatory terms and conditions and quality of its working institutions. Hence, the study aims to determine factors affecting FDI inflow in developing Asian countries with varied objectives.

The objectives are as follows:

To examine factors affecting FDI inflow

To study the impact of reforms on FDI inflow

To figure out the best regression technique for the purpose of the study and provide relevant suggestions focusing on the promotion of FDI inflows in these countries.

The study comprises Section 1 Introduction, Section 2 Literature Review, Section 3 Data, Meth- 
odology and Analysis, and Section 4 that includes Conclusion with the further scope of the study.

\section{Literature Review}

There exist various theories and studies that try to explain FDI inflow in any country and its trends and impact on the economy.

Hymer (1960) highlighted the issues related to barriers to entry like uncertainty, risk nationalism of host country, legal system and protectionist outlook of the nation for a firm which is keen to set up production abroad and Dunning (1997) introduced the world with the concept of "eclectic paradigm" also known as ownership, location, industrialisation model which companies follow to ascertain whether pursuing FDI is beneficial or not.

Quazi (2004) investigated the factors that drive FDI into countries of the South Asian continent: India, Pakistan, Nepal, Bangladesh, and Sri Lanka, where factors could be economic or non-economic. Quazi used economic freedom as one of the variables affecting FDI inflow which acts as a substitute for the domestic investment climate. The panel regression equation estimation along with the generalised least square method with corrections for heteroskedasticity and autocorrelation found that political instability reduced inflows of FDI in a country, whereas all other factors like economic prosperity, economic freedom, economic openness, human capital, and lagged changes in FDI meaningfully increased FDI inflows.

Adhikary and Mengistu (2008) provided a clear view that a higher production standard of FDI holds simply when the host country exhibits a minimum quantity of human capital and adequate infrastructure along with macroeconomic stability, market size and extent of openness alongside exchange rate stability, lower production costs and investment incentives.

Athukorala (2009) mentioned in his work that "determinants affecting FDI inflows are diverse and there is no complete list of FDI determinants though it is usually observed that the most popular determinants are market size, potential growth of the market, the openness of trade, exchange rate volatility, clustering effects of firms, political stability, institution, taxes, trade restriction, trade effects, productivity, labour cost and infrastructure."

Mottaleba and Kalirajanb (2010/13) mentioned that by tying together the gaps of native savings and investment and carrying the newest technology and management expertise from developing countries, FDI could perform a vital role in reaching rapid economic growth. The results from analysis of 68 countries for years 2005, 2006 and 2007 for over 8 variables were taken to infer variables critically affecting inflows of FDI in specific countries. The paper noted that small nations across the globe that are emergent could attract ample FDI just by embracing more outward focusing trade policy and proposing a more business welcoming environment in front of foreign investors.

Jha, Agarwal, Gupta, and Mishra (2012) analysed Bangladesh, Pakistan, India, Sri Lanka, Nepal and Maldives with parameters GDP, direct investment, trade openness, real effective exchange rate and labour is taken into consideration for years 1990-2010. The main tools of econometric analysis were Augmented Dickey Fuller test, Durbin Watson test and White test. The results were empirically defensible with the administrative and economic developments over 20 years. The adverse influence of labour on FDI was illuminated in the study.

Parashar (2015) investigated factors affecting FDI inflow in China and India over a stretch of 30 years from 1980-2013 using data on market size, infrastructure, trade openness, growth rate, policy changes, inflation and opportunity cost to investors collected from UNCTAD, World Bank, IMF, ILO database and Federal Reserve. Apart from the linear regression, the Dickey Fuller unit root test and Engel Granger co-integration test were performed to ascertain that market size and wage rate are the most important factors determining the flow of FDI. These are consistent with the market seeking and resource seeking hypothesis.

Huq, Khan and Rehman (2016) stressed more on Bangladesh while covering 4 other countries India, Nepal, Pakistan and Sri Lanka. They suggested that FDI is considered as one of the vital requirements for the overall development course of developing countries. The key concept of transmission mechanism was highlighted, and FDI was thought of as a contributor to economic development. FDI was thus seen as a reducer of poverty through preliminary macroeconomic stimulus and raiser of total factor productivity and efficiency of resource use in recipient economy through transmission mechanism which works between FDI and poverty reduction. 
Imtiaz and Bashir (2017) recognised FDI as one of the key funding sources for long-term maintainable economic advancement in developing countries. The conceptualisation of economic freedom as a provider of better investment climate important for foreign firms and MNC"s was done in which freedom referred to no constraint, burden or obligation in choice or exchange or transfer of personal assets. The panel data fixed and random effect model were used along with the Hausman specification test to analyse heterogeneity. Further, correlation analysis was conducted to identify the strength of linear association among the variables.

Rasheed (2019) studied 14 Asian countries from 2003-2017 to analyse the relationship between FDI and macroeconomic factors using panel data technique. The study concluded that macroeconomic indicators significantly affected FDI inflows in China, Hong Kong, Indonesia, Jordan, Pakistan, the Philippines, and Vietnam and revealed that trade openness and exchange rate are decisive economic indicators to attract FDI towards the economies.

\section{Data, Methodology and Analysis}

The World Bank published the data for conducting the study we collected from various datasets for 39 years. Data can be viewed as unbalanced panel data for the purpose of study where an unbalanced panel is defined as a dataset in which at least one-panel member is not observed every period; therefore, with $\mathrm{N}$ panel members and $\mathrm{T}$ periods, strict inequality holds for the number of observations $\mathrm{n}$ in the dataset: $\mathrm{n}<\mathrm{N}^{*} \mathrm{~T}$.

\section{About the Countries}

INDIA. A developing economy, $3^{\text {rd }}$ largest by Purchasing Power Parity (PPP), $5^{\text {th }}$ on world economy chart and ranked $142^{\text {nd }}$ on the basis of nominal GDP and per capita income basis respectively. India attracted a total of $\$ 58.37$ billion from April to November 2020, which accorded for the highest FDI inflow in a span of 8 months in a single financial year and showed a 22 per cent hike compared to the first eight months of the financial year 2019-20. Socialist cum politicians or politicians inspired by socialists has been the driving force of economic development since independence, including sector's state ownership. With the introduction of fundamental reforms and their renewals from
1991 onwards, India progressed to become a free market economy. IMF says that India can touch a level of 10 per cent if reforms are rightly pushed and with states taking utmost responsibility for the respective economies.

CHINA. Economy market a transition from centrally planned to market orientation. Apart from being $2^{\text {nd }}$ leading economy in terms of GDP and largest by PPP, China is one of the world's most recklessly growing economies with 6 per cent growth rate over the past 30 years. Being in $4^{\text {th }}$ and $11^{\text {th }}$ position in terms of inward and outward FDI, China tops the leading developing economies. A high growth base lies under resource-intensive exports and manufacturing and availability of labour at low cost. Reduction in economic, environmental and social imbalance has shifted structure from low to high-end services and manufacturing and a shift to consumption from investment.

MYANMAR. A lower-middle income country with US \$1,210 as its GNI per capita, an agriculture-based economy with the least development, having maximum population involved in agricultural pursuits directly. Here FDI started in 1973, and in 1988 military coup encouraged indigenous and private enterprise. The moderate growth is driven by a strong performance by the telecom industry and domestic trade along with relatively slow growth of the construction, manufacturing, and transport sector.

NEPAL: Economic development in the country became more complicated due to political scenarios and rising corruption. Till 1951 people of Nepal faced deprivation of even the basic amenities, gradually in the late 1950 s, the country made a progressive walk towards sustainable growth. By 1983 Nepal engaged itself in an investment protection agreement with various counties. Opening the country towards economic liberalisation with a perspective of economic growth and improved standard of living was a major step taken by the government of Nepal. Capacity in hydroelectricity played an important role in driving the economy. To promote FDI in the county government entered into double taxation agreements to avoid them with least 10 countries starting from 2000.

PAKISTAN. It is a semi-industrialised economy centralised along the Indus River, and exports being primarily based on commodities like leather goods, sports goods, textiles, chemicals, medical instruments and rugs. Removal of barriers to en- 
Table 1

Country wise sample size

\begin{tabular}{cccc}
\hline No & Country Name & Period & No. of years \\
\hline 1 & India & $1982-2020$ & 39 \\
2 & China & $1982-2020$ & 39 \\
3 & Myanmar & $1982-2020$ & 39 \\
4 & Nepal & $1982-2011$ & 26 \\
5 & Pakistan & $2004-2020$ & 17 \\
6 & Bangladesh & $1982-2020$ & 39 \\
7 & Bhutan & $2006-2020$ & 17 \\
Total & 7 & & 216 \\
\hline
\end{tabular}

Note. Data for years 1992-1995 is missing for Nepal due to unavailability of appropriate data.

Source: The author.

courage a free flow of capital and FDI was done to the extent of 100 per cent equity participation in many sectors, unlimited payment of profits, service fees, dividends and capital was made. Though doing business was getting easier but problem due to corruption, political instability and domestic insurgence worsened the conditions.

BANGLADESH. Economic with $39^{\text {th }}$ position in nominal terms and $29^{\text {th }}$ in PPP, it is strategically important to provide maritime access for landlocked regions, mainly Bhutan, Nepal, India, and potential gateway for China's landlocked areas. It is a house for major real estate investments. It saw expansion in the education system and food production and the development of technological and industrial bases and rose out of poverty. With the commencement of the mid-1990s, commitment towards the free market was observed by successive governments, privatisation of enterprise owned by the state, channelisation of investment and various banking reforms were seen.

BHUTAN. One of the major least developed and smallest economies, where agriculture and forestry play the most important role in fetching livelihood to around 60 per cent of the population. The major contributor of the overall growth rate here is exports of hydropower to its major market India supported by fiscal policies and monetary policies facilitating macroeconomic stability, characterised by lower rate of inflation, consistently steady exchange rate and accumulation of international reserves. The tremendous progress by reducing extreme poverty, gender equality promotion, and attention towards inequality issues adds to the country's progress. The philosophy of the country guides its development as given by Gross National Happiness (GNH). Hydropower development's ideal condition, i.e., abundance of water resources spurred growth and revenue generated from it helps in financing a large number of investments for the development of human capital in the country.

\section{About the Variables}

The secondary data is collected for the purpose of the study. We studied various variables to ascertain how changes in independent variables affect dependent variables.

Dependent variable: The variable that is tested and experimentally measured is known as a dependent variable. Here, the Inflow of Foreign Direct Investment is a dependent variable. These investments serve the interests of various investors putting their money in company or businesses in some distinct nations.

Independent variables: These variables can be controlled and changed to test the impact on a dependent variable.

1. Gross Domestic Product (GDP) is an indicator for depicting market size, which provides us with some understanding in accordance with endogenous growth theory stating that nation with large market size nurture faster-seeking benefits from economies of scale. Higher GDP or GDP growth rate attracts more FDI than the ones that are having a slow or stagnant growth rate.

2. Exports of goods, services and primary income are an important component of interna- 
Table 2

Measurement units of the variables

\begin{tabular}{cccc}
\hline No & Name of Factor & Variable & Measuring unit \\
\hline 1 & FDI Inflow & FDI & Current million USD \\
2 & Market size & GDP & Current million USD \\
3 & Value of currency & Exchange rate & LCU per USD \\
4 & Trade & Exports & Current million USD \\
5 & Trade & Imports & Current million USD \\
6 & Infrastructure & GFCF & \% of GDP \\
7 & Inflation & GDP deflator & Percentage \\
8 & Cost of borrowing & Interest rate & Percentage \\
9 & Economic reforms & Reforms & \\
\hline
\end{tabular}

Note. Log of GDP and exchange rate is used for better results that are more efficient and reliable.

Source: The author.

tional trade that offers a wider market to people and firms. Exporting to foreign markets generally decreases the unit cost of production, results in increased experience and knowledge, which may even facilitate the discovery of new marketing practices, technologies, and insights.

3. Imports of goods, services and primary income are other components of international trade. When countries are unable to produce cheaply and efficiently, they import goods from other countries. Apart from a finished product, raw materials that are unavailable in domestic countries are imported.

4. Gross Fixed Capital Formation (GFCF), also referred to as the net investment, measures the net increase in fixed capital, namely infrastructure by increased construction of railways, commercial buildings, residential dwellings, roads, and improvement of land. Building of capitalintensive assets requires a huge amount of sunk cost which gets recovered by the inflow of FDI in heavy amount.

5. Inflation rate is a quantitative measure at which the average price level of goods and services increases over time. It indicates a decrease in the PPP of the nation's currency. An ideal level of inflation is needed to encourage spending instead of savings, thereby nurturing economic growth.

6. Interest rate of any country plays a dynamic role in attracting inflows. It is paid when borrowings are made and received when a certain amount is saved. The fall in an economy's interest rate attracts more and more investors from the foreign base as they receive higher returns from the investment made.

7. Exchange rate accounts for an inverse relation with FDI. Though most studies

show a significant relationship between both, many studies contradict it. The ambiguous result is an outcome of the home country's currency, which leads to appreciation or depreciation of the recipient country's currency and its exchange rate.

8. Reforms played a vital role in determining inflows of FDI. It facilitated the liberalisation of FDI by waiving off restrictive conditions and obligations. The economic reforms of 1991 played a significant role in the economies of Asia. With the clear purpose of rapid industrialisation, elimination of industrial licensing, permission for foreign investment, encouragement to private and public sectors was done by the government. The main aspects of the reforms are Liberalisation, Privatisation and Globalisation.

The unit of measurement of all the variables used can be seen as under. In regression, analysis names are used according to the variable (not the name of the factor).

\section{Economic and Econometric Models}

The economic model suggests, inflows of FDI are a function of economic factors and can be written as FDI $=f$ (Economic factors). The econometric model suggests inflows of FDI is a dependent variable. In contrast, GDP, exports, imports, gross fixed capital formation, interest rate, GDP 
Table 3

Descriptive Statistics of variables

\begin{tabular}{lcccc}
\hline \multicolumn{1}{c}{ Variable } & Mean & SD & Min & Max \\
\hline FDI & 19500 & 54000 & -16.6 & 291000 \\
GDP & 25.06 & 2.42 & 20.58 & 30.24 \\
Exchange rate & 3.26 & 1.27 & 0.63 & 7.26 \\
Exports & 192000 & 542000 & 215 & 2890000 \\
Imports & 188000 & 497000 & 406 & 2830000 \\
Gross FCF & 26.12 & 11.22 & 9.48 & 68.02 \\
Inflation & 8.63 & 7.70 & -1.26 & 57.68 \\
Interest rate & 3.19 & 6.30 & -31.50 & 14.82 \\
Reform & 0.75 & 0.43 & 0 & 1 \\
\hline
\end{tabular}

Note. FDI, exports and imports are in 100 thousand million dollars. Also, SD stands for standard deviation and min, and max refers to the minimum and maximum value, respectively.

Source: The author.

deflator, exchange rate and reforms are independent variables or explanatory variables. The following two models are studied for the purpose of the study:

\section{Model 1}

$\mathrm{FDI}=\beta 0+\beta 1(\mathrm{GDP})+\beta 2($ exchange rate $)+$ $+\beta 3$ (exports) $+\beta 4$ (imports) $+\beta 5($ GFCF $)+$ $+\beta 6$ (interest rate) $+\beta 7$ (inflation) $+\mu$

\section{Model 2}

$\mathrm{FDI}=\beta 0+\beta 1(\mathrm{GDP})+\beta 2($ exchange rate $)+$ $+\beta 3$ (exports) $+\beta 4$ (imports) $+\beta 5($ GFCF $)+$ $\beta 6($ interest rate $)+\beta 7$ (inflation $)+\beta 8$ (reforms $)+$ $+\mu$

\section{Methodology}

Panel data is a combination of both time-series and cross-sectional data. In this behaviour is observed of entities across time. There are two significant benefits of using panel data.

First, panel data assures more reliable estimates of the parameters as it allows controlling those unobservable factors that may vary across units but not the time or may vary across time but not units.

The second benefit relies on the fact that identification and effects" measurement is possible in panel data. It is facilitated by the usage of different methods of analysis. These are the random effect regression model and fixed effect regression model.
Basic panel data analysis is POOLED OLS estimation, which is the easiest and simplest estimation method that allows pooling of observations over time and running OLS. In this, every observation is treated as a separate entity.

FIXED-EFFECT model is used for the analysis of the impact of variables that change over time. It explores the relationship between variables in an entity. FE removes the effects created by time-invariant characteristics of variables so as to create access to net effects on outcome variable by predictors.

RANDOM-EFFECT model relies on the rationale that variations across entities are assumed to be uncorrelated and random. The advantage of using RE is that the time-invariant variables can be included, and these effects are not absorbed by intercept as in the case of FE. This model assumes error terms being uncorrelated with predictors allowing time-invariant variables" role as an explanatory variable. It allows for the generalisation of inferences further than the sample used.

The first thing to look at is a descriptive analysis of the variables. The table below represents the basic statistics of all the variables.

Each variable included consists of $216 \mathrm{ob}$ servations for the panel of 7 developing Asian countries. Next, the Fisher Type Unit Root Test, developed by Maddala and $\mathrm{Wu}$ (1999), is used to test stationarity in panel data when the data used is unbalanced. Based on the $p-$ values generated 
by Dickey- fuller unit root test on each panel, the test assumes the following hypothesis, where

Null Hypothesis: Ho: pi $=1$ for all i, implies that all panels contain unit roots.

Alternative Hypothesis: Ha: $\mid$ pi $\mid<1$ for at least one i for finite $\mathrm{N}$.

Here exchange rate, inflation and interest rate have an order of integration 0 and follows $\mathrm{I}(0)$, whereas FDI, GDP, exports, imports, gross FCF and reforms follow I(1) as they have an order of integration 1.

We undertake correlation analysis in order to check the strength of linear association of variables with each other. Results of correlation analysis revealed that there is a very strong positive correlation between FDI and exports and FDI and imports as value approaches near 1. A moderately strong positive correlation is observed between FDI and GDP. Apart from this, FDI is positively correlated with gross FCF and reforms. A negative correlation is seen amongst FDI and exchange rate, FDI and inflation and FDI and interest rate.

Since the correlation of independent variables is less than 0.80 , it can be inferred that there is multicollinearity between the independent variables, which implies that collinearity will not have an impact on the results of the regression.

Similar can be observed graphically in Figure.

\section{Regression Analysis}

Coefficient values mentioned above are in hundred thousand million USD apart from exports and imports for which it is 0.0001 thousand million USD.

Table 6 shows that Pooled OLS and Random effect regression analysis results are similar, and fixed-effect regression results are different from them. The model accounts for the relationship of FDI inflow with GDP, exchange rate, exports, imports, gross FCF, interest rate and inflation.

Table 7 shows the results of model 2, which comprises all the variables as in model 6 and reform as an additional variable.

Coefficient values mentioned above are in hundred thousand million USD apart from exports and imports for which it is 0.0001 thousand million USD.

The overall value of $\mathrm{R}^{2}$, which provides insight of goodness of fit of any model, is a greater for model 2 as compared to model 1 in all the regression techniques signifying model 2 explains a greater
Table 4

Fisher-type unit root test

\begin{tabular}{lcc}
\hline Variable & $\begin{array}{c}\mathbf{p}-\text { value at } \\
\text { level }\end{array}$ & $\begin{array}{c}\mathbf{p}-\text { value at 1st } \\
\text { difference }\end{array}$ \\
\hline FDI & 0.5594 & $0.00^{* * *}$ \\
GDP & 0.9443 & $0.00^{* * *}$ \\
Exchange & $0.0026^{* * *}$ & - \\
rate & 0.5274 & $0.00^{* * *}$ \\
Exports & 1.00 & $0.00^{* * *}$ \\
Imports & 0.6864 & $0.00^{* * *}$ \\
Gross FCF & $0.00^{* * *}$ & - \\
Inflation & $0.00^{* * *}$ & - \\
Interest & 0.9589 & $0.00^{* * *}$ \\
rate & & \\
Reform & &
\end{tabular}

${ }^{* * *} p<0.01$ (1\% level of significance), ${ }^{* *} p<0.05$ (5\% level of significance), ${ }^{*} p<0.1$ (10\% level of significance).

${ }^{* * *}$ indicates that the null hypothesis is rejected at $1 \%$ level of significance, implying that at least one panel is stationary and exhibits no unit root.

Source: The author.

amount of variations caused by independent variables in our dependent variable. This greater value implies that our additional variable, i.e., reforms accounts for a significant impact over dependent variable FDI inflows. Apart from observing the value of $\mathrm{R}^{2}$ for ascertaining the best model, diagnostic tests are performed to specify which method of regression will enable us to draw the best result.

Hausman Specification Test. The test is used to determine whether the fixed effect model or random effect model is best for regression. The test compares an estimator which is known to be consistent with an estimator that is efficient under the assumption being tested.

Null Hypothesis: Ho: The difference in coefficients is not systematic.

Alternative Hypothesis: Ha: Difference in coefficients is systematic.

Our null hypothesis that difference in coefficients is not systematic, i.e., the model is random effect model is rejected as the probability is lesser than 0.05 . It implies that fixed effect regression suits better to the model.

Testing for Time Fixed Effect. Testparm command is run to ascertain whether time fixed effects are needed over fixed effect regression model. It 


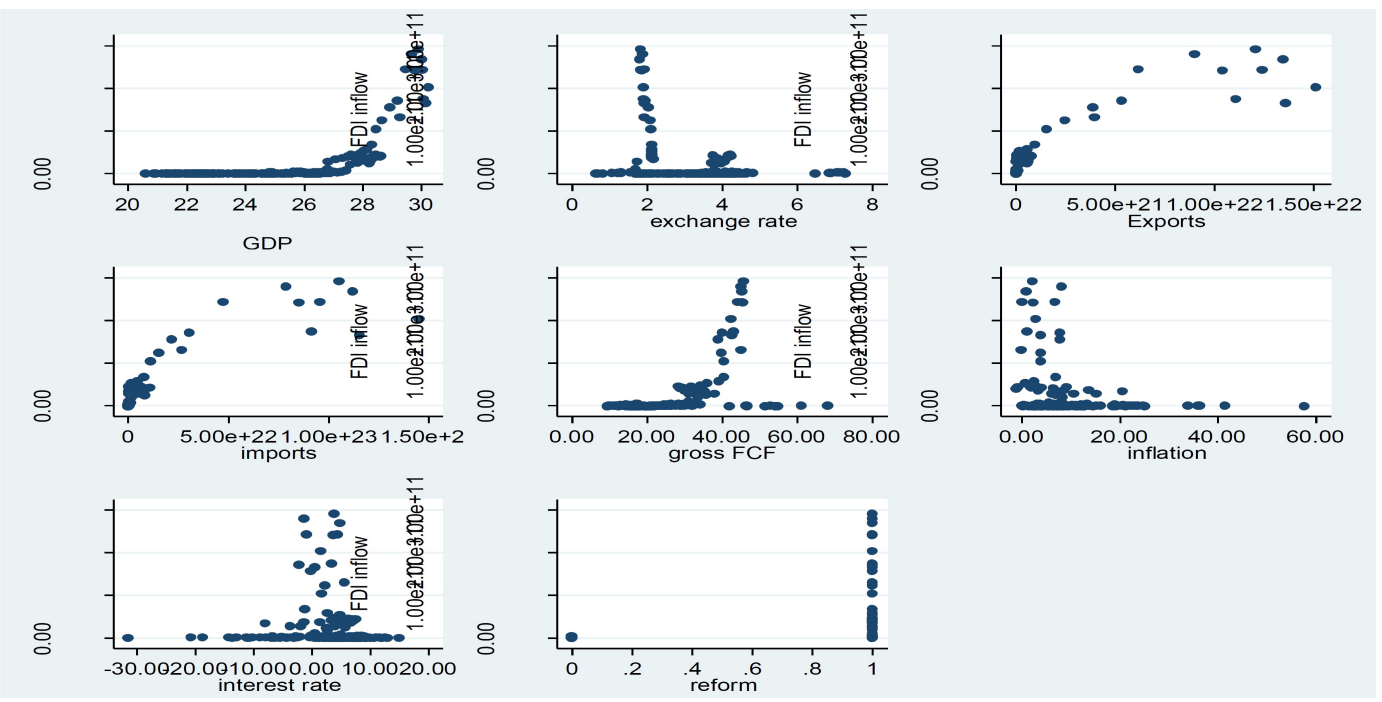

Fig. Graphical representation of a correlation

Source: The author.

Table 5

Correlation Analysis

\begin{tabular}{|c|c|c|c|c|c|c|c|c|c|}
\hline Variable & FDI & GDP & $\begin{array}{c}\text { Exchange } \\
\text { rate }\end{array}$ & Exports & Imports & $\begin{array}{c}\text { Gross } \\
\text { FCF }\end{array}$ & Inflation & $\begin{array}{c}\text { Interest } \\
\text { rate }\end{array}$ & Reform \\
\hline FDI & 100 & & & & & & & & \\
\hline GDP & 0.61 & 1.00 & & & & & & & \\
\hline $\begin{array}{l}\text { Exchange } \\
\text { rate }\end{array}$ & -0.29 & -0.13 & 1.00 & & & & & & \\
\hline Exports & 0.91 & 0.49 & -0.25 & 1.00 & & & & & \\
\hline Imports & 0.89 & 0.49 & -0.24 & 0.79 & 1.00 & & & & \\
\hline Gross FCF & 0.46 & 0.29 & 0.05 & 0.38 & 0.37 & 1.00 & & & \\
\hline Inflation & -0.20 & -0.3 & -0.25 & -0.18 & -0.17 & -0.42 & 1.00 & & \\
\hline Interest rate & -0.05 & 0.12 & 0.34 & -0.03 & -0.03 & 0.29 & -0.76 & 1.00 & \\
\hline Reform & 0.20 & 0.21 & 0.37 & 0.14 & 0.14 & 0.29 & -0.12 & 0.07 & 1.00 \\
\hline
\end{tabular}

Source: The author.

sees if the coefficients are jointly equal to zero for all the years or not.

Null Hypothesis: Ho: Coefficients are jointly equal to 0 for all the years.

Alternative Hypothesis: Ha: Coefficients are equal to 0 .

Since probability is less than 0.05 null hypothesis can be rejected, which means that coefficients are not jointly equal to 0 for all the years, implying that time fixed effects are essential.

Breusch Pegan Lagrange Multiplier Test. This test helped to decide between the random effect regression model and pooled OLS regres- sion model. It checks whether variance across entities is zero or not.

Null Hypothesis: Ho: Pooled OLS regression model is appropriate.

Alternative Hypothesis: Ha: Random effect model is appropriate.

Since probability is 1 , we cannot reject the null hypothesis, concluding that pooled OLS model is more appropriate.

\section{Comparison of Models}

Initially, for choosing between the two models that is model 1 showing the relationship between FDI 
Table 6

Results of pooled OLS, fixed-effect and random-effect regression for model 1

\begin{tabular}{|c|c|c|c|}
\hline Independent variable & Pooled OLS & Fixed- effect & Random- effect \\
\hline GDP & $\begin{array}{l}3890^{* * *} \\
(589)\end{array}$ & $\begin{array}{c}12100^{* * *} \\
(2560)\end{array}$ & $\begin{array}{l}3890^{* * *} \\
(589)\end{array}$ \\
\hline Exchange rate & $\begin{array}{l}-1720^{*} \\
(1010)\end{array}$ & $\begin{array}{l}-3700^{* *} \\
(1730)\end{array}$ & $\begin{array}{l}-1720^{*} \\
(1010)\end{array}$ \\
\hline Exports & $\begin{array}{l}0.00475^{* * *} \\
(0.000476)\end{array}$ & $\begin{array}{l}0.00432^{* * *} \\
(0.000482)\end{array}$ & $\begin{array}{c}0.00475^{* * *} \\
(0.000476)\end{array}$ \\
\hline Imports & $\begin{array}{c}-0.000372^{* * *} \\
(0.0000552)\end{array}$ & $\begin{array}{l}-0.00034^{* * *} \\
(0.000055)\end{array}$ & $\begin{array}{c}-0.000372^{* * * *} \\
(0.0000552)\end{array}$ \\
\hline Gross FCF & $\begin{array}{l}536^{* * *} \\
(122)\end{array}$ & $\begin{array}{l}263 \\
(337)\end{array}$ & $\begin{array}{l}536^{* * *} \\
(122)\end{array}$ \\
\hline Inflation & $\begin{array}{l}-696^{*} \\
(360)\end{array}$ & $\begin{array}{l}-118 \\
(424)\end{array}$ & $\begin{array}{l}-696^{*} \\
(360)\end{array}$ \\
\hline Interest rate & $\begin{array}{c}-1230^{* * *} \\
(417)\end{array}$ & $\begin{array}{l}-507 \\
(489)\end{array}$ & $\begin{array}{c}-1230^{* * *} \\
(417)\end{array}$ \\
\hline Constant & $\begin{array}{c}-87000^{* * *} \\
(17200)\end{array}$ & $\begin{array}{c}-286000^{* * *} \\
(58600)\end{array}$ & $\begin{array}{c}-87000^{* * *} \\
(17200)\end{array}$ \\
\hline $\begin{array}{l}\mathrm{R}^{2} \\
\text { (within) } \\
\text { (between) }\end{array}$ & $\begin{array}{c}0.9091 \\
- \\
-\end{array}$ & $\begin{array}{c}- \\
0.8597 \\
-\end{array}$ & $\begin{array}{c}- \\
0.8499 \\
0.9917\end{array}$ \\
\hline Adjusted $\mathrm{R}^{2}$ & 0.9058 & - & - \\
\hline F-statistic & 277.17 & 164.62 & - \\
\hline F (p-value) & 0.00 & 0.00 & - \\
\hline Chi2 (p-value) & - & - & 0.00 \\
\hline Observations & 216 & 216 & 216 \\
\hline Countries & 7 & 7 & 7 \\
\hline
\end{tabular}

Source: The author.

Notes

Standard errors in parenthesis.

${ }^{* * *} p<0.01$ ( $1 \%$ level of significance), ${ }^{* *} p<0.05$ (5\% level of significance),

${ }^{*} p<0.10$ (10\% level of significance)

and GDP, exports, imports, gross FCF, inflation and interest rate and model 2 showing the relationship between FDI and GDP, exports, imports, gross FCF, inflation, interest rate a reforms goodness of fit is compared which shows that $\mathrm{R}^{2}$ is greater for model 2 .

The choice between Pooled OLS, fixed effect and random effect regression model on the basis of the significance of variables is made. In Pooled OLS and random effect regression model, all our independent variable are statistically significant, and in fixed effect regression, only GDP, exchange rate, exports and imports are statistically significant in explaining the dependent variable FDI inflow. More variables are statistically significant in Pooled OLS and random effect regression model.

Hausman specification test suggests that fixed effect regression model should be considered over random effect regression model. By testing for the time fixe effect, it is ensured that the time fixed effect is important. And by BPL multiplier test results, we see pooled OLS method is more appropriate as compared to random effect regression. Considering 
Table 7

Results of Pooled OLS, fixed-effect and random-effect regression for model 2

\begin{tabular}{|c|c|c|c|}
\hline Independent variable & Pooled OLS & Fixed- effect & Random- effect \\
\hline GDP & $\begin{array}{l}3670^{* * *} \\
(597)\end{array}$ & $\begin{array}{l}11400^{* * *} \\
(2960)\end{array}$ & $\begin{array}{l}3670^{* * *} \\
(597)\end{array}$ \\
\hline Exchange rate & $\begin{array}{c}-2690^{* *} \\
(1130)\end{array}$ & $\begin{array}{c}-3760^{* *} \\
(1730)\end{array}$ & $\begin{array}{c}-2690^{* *} \\
(1130)\end{array}$ \\
\hline Exports & $\begin{array}{r}0.0047^{* * *} \\
(0.000474)\end{array}$ & $\begin{array}{c}0.00433^{* * *} \\
(0.000483)\end{array}$ & $\begin{array}{l}0.000047^{* * *} \\
(0.000474)\end{array}$ \\
\hline Imports & $\begin{array}{l}-0.00036^{* * *} \\
(0.0000521)\end{array}$ & $\begin{array}{l}-0.000342^{* * *} \\
(0.0000551)\end{array}$ & $\begin{array}{l}-0.000367^{* * *} \\
(0.0000549)\end{array}$ \\
\hline Gross FCF & $\begin{array}{l}479 * * * \\
(125)\end{array}$ & $\begin{array}{l}278 \\
(339)\end{array}$ & $\begin{array}{l}479 * * * \\
(125)\end{array}$ \\
\hline Inflation & $\begin{array}{c}-739 * * \\
(359)\end{array}$ & $\begin{array}{l}-135 \\
(426)\end{array}$ & $\begin{array}{c}-739 * * \\
(359)\end{array}$ \\
\hline Interest rate & $\begin{array}{c}-1200^{* * *} \\
(414)\end{array}$ & $\begin{array}{l}-511 \\
(490)\end{array}$ & $\begin{array}{c}-1200^{* * *} \\
(414)\end{array}$ \\
\hline Reform & $\begin{array}{l}6050 * \\
(3140)\end{array}$ & $\begin{array}{l}1800 \\
(3600)\end{array}$ & $\begin{array}{l}6050^{*} \\
(3140)\end{array}$ \\
\hline Constant & $\begin{array}{c}-80900^{* * *} \\
(17400)\end{array}$ & $\begin{array}{c}-269000^{* * *} \\
(67800)\end{array}$ & $\begin{array}{c}-80900^{* * *} \\
(17400)\end{array}$ \\
\hline $\begin{array}{l}\mathrm{R}^{2} \\
\text { (within) } \\
\text { (between) }\end{array}$ & $\begin{array}{c}0.9108 \\
- \\
-\end{array}$ & $\begin{array}{c}- \\
0.8599 \\
-\end{array}$ & $\begin{array}{c}- \\
0.8529 \\
0.9908\end{array}$ \\
\hline Adjusted $\mathrm{R}^{2}$ & 0.9071 & - & - \\
\hline F-statistic & 246.37 & 143.5 & - \\
\hline F (p-value) & 0.00 & 0.00 & - \\
\hline Chi2(p-value) & - & - & 0.00 \\
\hline Observations & 216 & 216 & 216 \\
\hline Countries & 7 & 7 & 7 \\
\hline
\end{tabular}

Source: The author.

Notes

Standard errors in parentheses.

${ }^{* * *} p<0.01$ ( $1 \%$ level of significance), ${ }^{* *} p<0.05$ (5\% level of significance), ${ }^{*} p<0.10$ (10\% level of significance)

varied results, we conclude that fixed effect regression and pooled OLS regression suits better to the study conducted.

\section{Conclusion}

FDI plays an important role in amending economies of developing Asian countries, which raises the interest to know more about FDI and factors that greatly influence inflows of FDI. There exist many factors that affect FDI inflow, out of which here attempts are made to study a few, namely market size, the value of the currency, trade, infrastructure, inflation, cost of borrowing and economic reforms with the help of data on variables GDP, exchange rate, exports, imports, gross fixed capital formation, GDP deflator, interest rate and reform of seven countries India, Chine, Nepal, Bhutan, $\mathrm{Pa}-$ kistan, Bangladesh, and Myanmar for the period 1982-2020.

The common variables significant in all the types of models and techniques are GDP, exchange rate, exports, and imports. Pooled OLS and random ef- 
fect showed the other variables gross FCF, interest rate, inflation, and reforms significant along with above 4 .

Policymakers of developing Asian countries have taken various measures by far and surely need more initiatives to improve the influential tools of growth and development of economies of developing Asian countries. The increased need for attracting FDI is seen in the pursuit of sustainable growth and the belief that inflows of FDI result in growth automatically. However, FDI does not lead to automatic growth and requires huge absorption capacity to guarantee spillovers, policies and regulations that balance out rights of investors and public interest and active role of government in enhancing absorption capacity by harmonising economic, environmental, and social dimensions in accord with internationally recognised standards and principles.

\section{Recommendations}

1. Focus on liberalisation of the industrial sector by emphasising the openness of trade and integration of developing Asian countries with global economies for economic development has been proved as an asset for India and China. It needs an extension in other countries too.

2 . Following more rigorous reforms like permitting percentage ownership rights under automatic route of FDI in manufacturing of the medical device, telecom and railways, increased cap on FDI in insurance and defence sector, increasing FDI threshold and relaxation of sourcing reforms.

3. Existence of significant intraregional FDI inflows, low labour cost, active governmental role in liberalisation, and FDI promotion and strategies in favour of controlled inflation in developing Asian countries are paying off well for these economies. To achieve higher goals of growth, these economies control on inflation is needed to a greater extent as increasing inflation has a negative impact on FDI.

4. A perfect balance of the public and private sector working together towards better implementations of economic reforms will surely head towards upgrading economies.

5. Conscious attempts to encourage emigrant investments by the strengthening of commercial and economic diplomacy are a must to be taken.

6. Control on corruption at the end of both government and citizens is one of the major concerns that can facilitate increased FDI inflows in these countries when controlled.
Table 8

Result of Hausman specification test

\begin{tabular}{cc}
\hline $\mathrm{Chi}^{2}$ & 18.33 \\
Prob $>\mathrm{Chi}^{2}$ & 0.0055 \\
\hline
\end{tabular}

Source: The author.

Table 9

Result of testing for time fixed effect

\begin{tabular}{cc}
$\mathrm{Chi}^{2}$ & $\mathbf{5 8 3 8 . 2 3}$ \\
Prob $>\mathrm{Chi}^{2}$ & 0.00 \\
\hline
\end{tabular}

Source: The author.

Table 10

Breusch Pegan Lagrange multiplier test result

\begin{tabular}{cc}
\hline Chibar $^{2}$ & 0.00 \\
Prob $>$ chibar $^{2}$ & 1.00 \\
\hline
\end{tabular}

Source: The author.

7. It is observed that the availability of adequate roads, transport system, power, and water is still a major concern in attracting FDI. A hefty amount of efforts from the government's end will play a vital role in enhancing growth.

8. A little relaxation of labour law can work wonders for these economies as stern labour laws discourage Greenfield FDI in the economies.

9. Other hurdles seen in developing Asian economies that need relation are high tariff barriers, red tapism to massive extent, excessive bureaucracy and perception barriers that require a close check as FDI inflows are affected negatively by them.

10. Policies like double taxation avoidance treaty, from the bucket of tax regime's main achievements of the Indian system, are needed. It boosts investors' level of confidence because the tax on dividends and corporate profits are disincentives for the investors.

\section{Limitations}

1. Since the data source is secondary; the data is unbalanced due to the non-approachability of some sources.

2. There is a scope of extension of sample size and a number of countries used in the study.

3. Hands can be extended towards FDI outflows also.

4. And, always, there is a scope of adding more variables. 


\section{References}

Adhikary, Bishnu, \& Mengistu, Alemu Aye. (2018). Factors Influencing Foreign Direct Investment (FDI) in "South" and "Southeast" Asian Economies. The Journal of World Investment \& Trade, 9(5), pp. 427-437. DOI:10.1163/221190008X00223.

Authukorala, Prema-chandra. (2010). Production networks and trade patterns in East Asia: Regionalisation or Globalisation? ADB Working Paper Series on Regional Economic Integration No. 56

Imtiaz, Sadia, \& Bashir, Malik Fahim. (2017), Economic freedom and foreign direct investment in South Asian countries. Theoretical and Applied Economics, 2(611), pp. 281-294.

Jha, G.M., Agrawal, A., Gupta, A., \& Mishra, A.K. (2013). Determinants of FDI in South Asia. International Research Journal of Social Sciences, 2(1), pp. 1-6. Available online at: www.isca.in.

Mottaleb, Khondoker Abdul, \& Kalirajan, Kaliappa. (2010). Determinants of Foreign Direct Investment in Developing Countries: A Comparative Analysis. ASARC Working Paper 2010/13.

Sumit Parashar. (2015). Factors affecting FDI inflow in China and India. CHINA INSTITUTE, UALBERTA. https://www.ualberta.ca/china-institute/media-library/media-gallery/research/research-papers/fdichinaandindiasumitparashar201507.pdf.

Moudud-Ul-Huq, Syed, Khan, Abdul Mannan, \& Rahman, Habibur. (2016). FDI and Bangladesh: A study of South Asian territories. Management Studies and Economic System, 2(3), pp. 219-239

Quazi, Rahim M., \& Munir, Mahmud. (2004). Determinants of FDI in South Asia. https://www.researchgate.net/ publication/237345580_Determinants_of_Foreign_Direct_Investment_in_South_Asia.

Sahoo, Pravakar. (2006). Foreign direct investment in South Asia: policy, trends, impact and determinants. ABD Institute Discussion Paper No. 56.

Qamar Rasheed. (2019). Macroeconomic factors of FDI inflows in Asian economies: A study of 14 Asian countries. International Journal of Advanced Research, 7(2), pp. 289-300. DOI:10.21474/IJAR 01/8487

\section{ABOUT THE AUTHOR}

MA Economics, University School of Humanities and Social Sciences

Guru Gobind Singh Indraprastha University

E-mail: parul.g1107@gmail.com

Education:

2020 MA Economics (USHSS, GGSIPU)

2018 BA (H) Economics (SGGSCC, Delhi University)

\section{Academic projects and short courses of last three years}

Assessment of factors affecting FDI in developing Asian countries - The dissertation work was aimed to determine the factors affecting FDI inflows in developing Asian countries. It concerns the countries that represent economies that are progressing from being aid-dependent to trading giants. Examination of factors, analysis of the impact of reforms and relevant suggestions were proposed along with the estimation of the best regression technique for the purpose of study for 1982-2018.

Analysing GDP of India - The research project aimed to analyse how different sectors (Agriculture, forestry and fishing; Mining and quarrying; Manufacturing; Electricity, gas and water supply; Construction; Trade, hotels, transport and communication; Financing and real estate and Community, social and personal services) in the economy of a nation contributes in the GDP calculated at factor cost, i.e., GDP and how GDP at factor cost changes over time, based on the past and present behaviour of itself and other sectors contributing towards it. Overview of GDP of India and factors affecting it - The study uses quantitative methodology and secondary time series data for the period 1999-2014. The ordinary least squared (OLS) method is used to regress GDP, which is the proxy for economic growth on agriculture, industries, services, export, import, and money supply and establishes a meaningful relationship.

Impact of Oil and Non-Oil Exports on Nigerian Economy - The study examines the impact of oil and non-oil exports on the Nigerian economy post-1980s. It reviews and compares these sectors' contribution to Nigeria's GDP over the years and the reason for that pattern and level of performance.

Analysing the Impact of Reliance Share Prices and Crude Oil on Nifty - The study examines the relationship between Nifty50 and Crude Oil as the Dependent and Independent variable, respectively, in the stock market. 
Moreover, the relationship is examined when another independent variable: Reliance has been added to make the model multivariate. The direction and magnitude of impact that it brings to the model was investigated.

Area of interest: data analysis, financial analysis, research and development, management and public relations, credit portfolio analyst.

\title{
Оценка факторов, влияющих на ПИИ в развивающихся странах Азии
}

\section{Парул Гупта}

\begin{abstract}
АННОТАЦИЯ
В статье рассматриваются различные факторы, влияющие на приток прямых иностранных инвестиций в Индию, Китай, Мьянму, Непал, Пакистан, Бангладеш и Бутан, а также в другие азиатские страны, которые постепенно превращаются в индустриальные и торговые гиганты. Факторы, влияющие на ПИИ, в основном подразделяются на зависимые и независимые переменные. В данном исследовании в качестве зависимой переменной рассматривается приток прямых иностранных инвестиций, а независимыми переменными являются размер рынка, стоимость валюты, экспорт, импорт, валовое накопление основного капитала, дефлятор ВВП, стоимость заимствований и экономические реформы. Объединенный обыкновенный метод наименьших квадратов (OLS), регрессионный анализ с фиксированным и случайным эффектами, а также различные тесты проводятся для определения лучшей регрессионной модели и проверки интенсивности эффекта, вызванного каждой независимой переменной на зависимую переменную.

Ключевые слова: прямые иностранные инвестиции (ПИИ); Валовой внутренний продукт (ВВП); обычный метод наименьших квадратов (OLS); Валовое накопление основного капитала (BHOK)

\section{ОБ АВТОРЕ}

Парул Гупта - магистр экономики, University School of Humanities and Social Sciences, Guru Gobind Singh Indraprastha University, Third Floor, C Block, GGSIP University, Dwarka, Sector 16 C, Kakrola, Delhi, 110075, India. В последнее три года принимал участие в реализации следующих проектов: «Оценка факторов, влияющих на ПИИ в развивающихся странах Азии», «Анализ ВВП Индии», «Обзор ВВП Индии и факторов, влияющих на него», «Влияние экспорта нефти и других товаров на экономику Нигерии».
\end{abstract}

